\title{
術前補助的治療による骨原発悪性腫瘍 周囲の反応層の変化
}

\author{
長崎大学整形外科 \\ 平 野徹・岩 崎 勝 郎 \\ 神代敏之・貞松俊弘 \\ 山田健 治
}

Effect of Preoperative Adjuvant Treatment on the Reactive Zone of Malignant Bone Tumors.

by

Toru Hirano, Katsuro Iwasaki, Toshiyuki Kumashiro, Toshihiro Sadamatsu and Kenji Yamada

Department of Orthopaedic Surgery, Nagasaki Uuiversity School of Medicine.

\begin{abstract}
We observed microscopically the effects of preoperative adjuvant treatment on the reactive zone surrounding the neoplasmas in 14 cases of osteosarcoma, 3 cases of Ewing's sarcoma and 2 cases of MFH of bone. The reactive zone of biopsied specimens, which showed peritumoral edema and perivascular lymphocytic infiltration, was transformed into a thick membranous capsule in resected specimens after the treatment. The extramedullary component invading the periosteal soft tissues was completely covered with a thick membranous capsule. Invading foci within skeletal muscles were nearly covered with not a thick membranous capsule but a scar tissue mixed with striated muscle fibers. However, no capsular structures were seen around the intramedullary component.

These findings might indicate that preoperative adjuvant treatment is of use to reduce the safety margin near the extramedullary component of the neoplasmas in the limb sparing surgery.
\end{abstract}

\section{はじめに}

近年，四肢原発の悪性骨腫瘍に対して盛んに患肢温 存治療が行われているが, 局所再発を防ぐためには, 腫瘍浸潤巣とその周囲にみられる反応層を確実に切除 する必要がある.

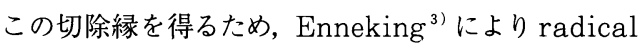
wide margin の概念が，また本邦では，川ロ によ $り$ curative wide margin の概念が提唱されている. しかし，これらでは術前の補助的治療の効果は考慮さ れておらず, 最近では出来るだけ良好な患肢機能の温 存を計るため, 切除縁縮少を目的とした補助的治療の
重要性も指摘される様になった ${ }^{6), 13)}$.

しかし腫瘍とともに切除されるべき浸潤巣周囲の反 応層が, 補助的治療によってどのように变化するか. その変化が腫瘍浸潤部位によって差があるかなどにっ いては，十分に検討されていない，そこで我々は，こ れらの点を明らかにする目的で組織学的検索を行った.

\section{対象および方法}

当教室で治療した骨原発悪性腫瘍のうち, 1984 年 以降, 補助的治療を行った後, 手術を施行した 19 例 を対象とした，病理診断のため 18 例で open biopsy を，1例で needle biopsy を行った。その診断の内 
表 1 系統的化学療法と放射線療法を併用した術前の補助的治療

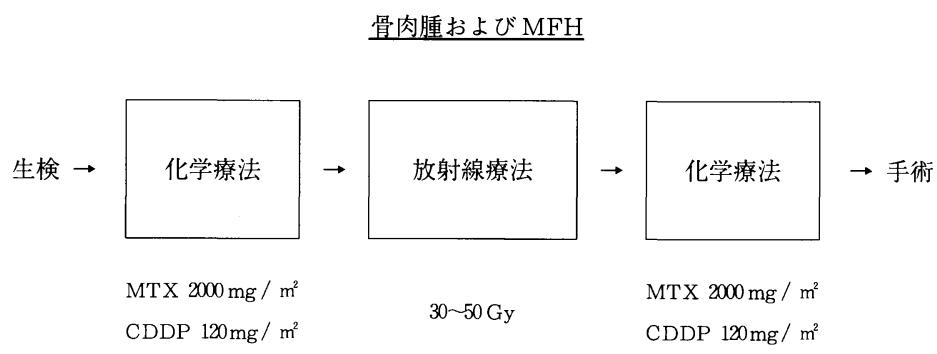

Ewing 肉腫

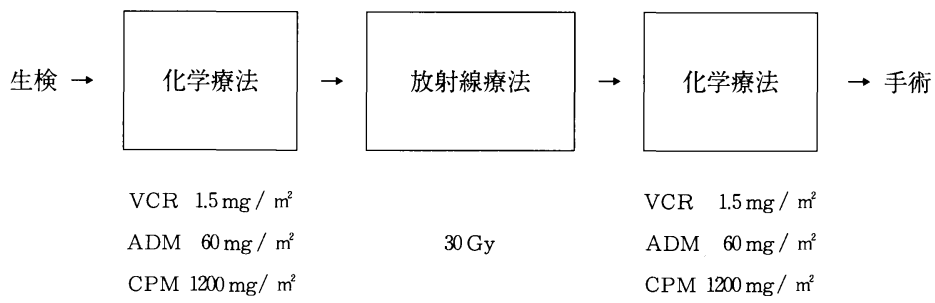

訳けは骨肉腫 14 例（骨膜性骨肉腫 1 例を含む）, Ewing, 肉腫 3 例, 骨原発悪性線維性組織球腫（以下, 骨原発 MFH） 2 例であり, Ennking の surgical staging system $^{3)}$ でII B が 18 例, III が1例であった.

術前の補助的治療は, 表 1 に示すごとく全例で 2 cycles の全身的化学治療法と, その間で 30 ないし 50 GyのLiniac X 線照射を行った. 化学療法として, 骨肉腫と骨原発 MFH には Methotrexate $(2000 \mathrm{mg}$ $/ \mathrm{m}^{2}$ を 90 分で静注）とCisplatinum (120 mg/m² を 3 日間で分割点滴静注）を主体にした投与を， Ewing 肉腫にはVincristine $\left(1.5 \mathrm{mg} / \mathrm{m}^{2}\right.$ を 6 時間で点滴 静注), Adriamycine $\left(60 \mathrm{mg} / \mathrm{m}^{2}\right.$ を 3 日間で分割点 滴静注）および Cyclophosphamide $\left(1200 \mathrm{mg} / \mathrm{m}^{2}\right.$ を 6 時間で点滴静注）の投与を行った ${ }^{212}$. 手術とし ては, 16 例で患肢温存のための広汎切除を, 3 例で 切離断術を行った。

組織学的には, 手術時に摘出した切除標本から, 生 検採取部位の切片と最も軟部組織へ浸潤していた部位 を含む全割切片を作製し, HE 染色とMallory's azan 染色を行った，そして補助的治療による腫瘍周
囲組織の変化を検索するため, 生検標本と切除標本の 生検採取部位を比較した. また切除標本から作製した 全割切片を用いて, 腫瘍浸潤部位別の変化の違いを検 討した.

結果

\section{1. 生検標本と切除標本における腫場周囲組織の比較}

生検標本で，腫瘍周囲組織を観察できたのは 14 例 であるが, この全例に反応層と呼ばれる浮腫, リンパ 球の浸潤, 毛細管内反細胞の肥大などの所見が認めら

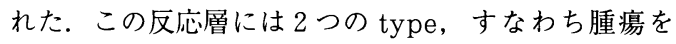
被うような骨膜などの被膜様構造物（偽被膜）を有す るもの（6例）と偽被膜を欠くもの（8例）がみられ た. 偽被膜を欠くものの中では， 5 例が脂肪織を混じ えた疎性結合織からなり，3 例は横紋筋肉に深く浸潤 していた（図 1 ABC).

補助的治療によって, 14 例の切除標本の腫瘍周囲 組織から反応層の所見は完全に消失し, 厚い膠原線維 によって被包化されていた，生検標本で偽被膜がみら れた 6 例と疎性結合織内に浸潤していた 5 例では, 膠 


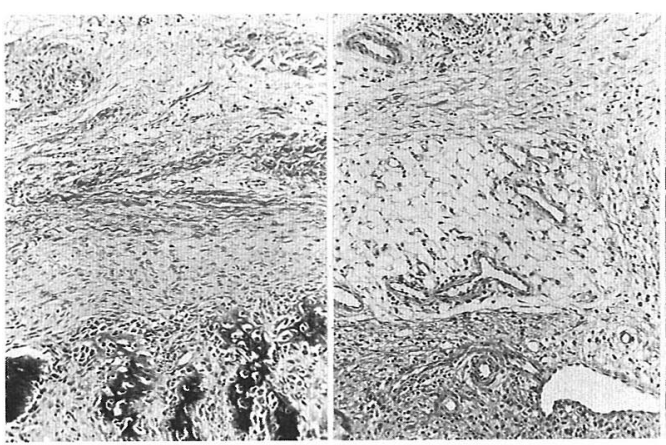

A

B

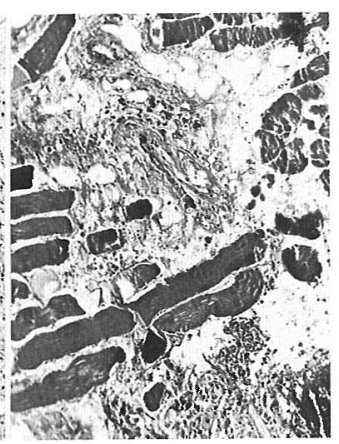

C

図1 骨肉腫生検標本の組織像. HE 染色， $\times 100 、 \mathrm{~A}$ : 腫瘍表面には，偽被膜が認めら れる。 B : 疎性結合織への浸潤部．偽被膜はみられない， C : 横紋筋内への不規則 な浸潤巣.

表 2 生検標本と切除標本における腫瘍周囲組織所見 の比較

\begin{tabular}{c|cc}
\hline \hline 生 検 標 本 & \multicolumn{2}{|c}{ 切除標 本 } \\
\hline 反応層内 & \multicolumn{2}{|c}{ 腫瘍の被包化 } \\
偽被膜 & 結合織性被膜 㿍痕組織 \\
$(+) ; 6$ 例 & 6 例 & \\
$(-) ; 8$ 例 & 5 例 & 3 例 \\
\hline
\end{tabular}

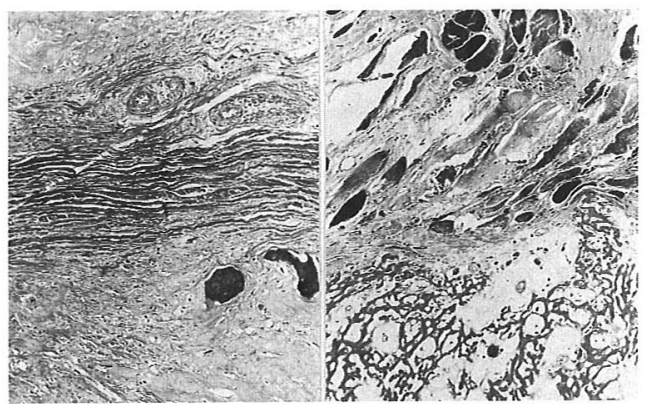

A

図 2 骨肉腫切除標本の組織像. HE 染色, $\times 100$. $\mathrm{A}$ : 疎性結合織内への浸潤部. 厚い噖原線維性 被膜が下方の変性壊死化した腫瘍組織を被って いる. B : 横紋笳の浸潤部.下方の腫瘍組織に 接して，横紋筋線維を混じえた㓔痕がみられる.

原線維は硝子化し，厚く層状化した被膜を形成してい た（図 2 A)。これに対して，横紋筋内に深く浸潤し ていた例では，腫瘍組織は横䋌筋線維を混じえた㓔痕 様結合織で被われていた（図 2 B）。これらの変化に， 骨原発悪性腫痬の組織型の違いによる差みられなかっ
表 3 腫瘍浸潤部位別の検索症例数と被包化の割合

\begin{tabular}{l|ccc}
\hline \hline 浸潤部位 & $\begin{array}{c}\text { 被包化 } \\
(-)\end{array}$ & $\begin{array}{c}\text { 被包化 } \\
(+)\end{array}$ \\
\hline $\begin{array}{l}\text { 骨髄組織 } \\
\text { 骨膜周囲の }\end{array}$ & $18 / 18$ & & \\
疎性結合織性被膜 & & & 瘕痕組織 \\
\hline 横紋筋組織 & & $14 / 19$ & $5 / 19$ \\
\hline
\end{tabular}

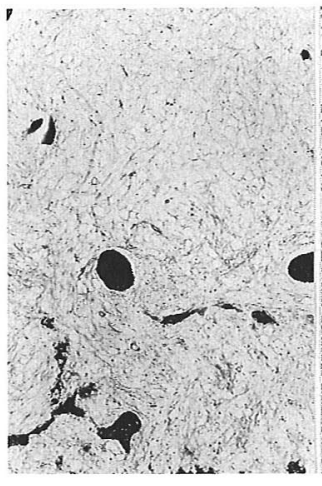

A

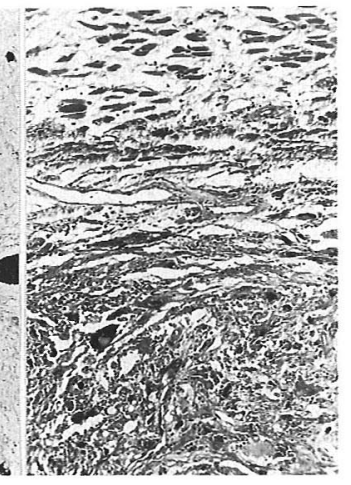

図 $3 \mathrm{~A}$ ：骨肉腫切除標本。骨髄内浸潤巣辺縁には, 被膜形成はみられない. HE 染色, ×40. B : 骨原発 MFH の切除標本。横紋筋と接する部分 に線維性被膜の形成はみられない. HE 染色 $\times$ 100.

た。

2. 切除標本の全割切片における腫瘍浸潤部位別の被 包化の差異 
腫瘍浸潤部位を，骨髄組織と骨外の骨膜周囲の脂肪 織を混じえた疎性結合織および横紋筋組織の 3 つに分 けて 19 例の全割切片を観察した結果，骨髄組織では 骨膜性骨肉腫を除く 18 例全てで被包化は認められな かった（表 3 ，図 $3 \mathrm{~A}$ ）。これに対して骨膜周囲の疎 性結合織部では完全に被包化されており，結合織性被 膜よりなっていた. 腫瘍組織が横紋筋内へ深く浸潤し ていた 5 例では，その大部分が曒痕様組織で被われて いた．瘢痕様組織で完全に被包化されていたのは 1 例 だけであった４例では一部に被包化されていない所 が認められ，ここにはいずれも viable な腫瘍細胞が 充実性に増殖していた（図 3 B）.

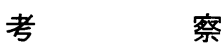

骨原発悪性腫瘍に対する術前の補助的治療は，系統 的化学療法単独あるいは系統的化学療法に放射線療法 を併用したものなどその内容はさまざまであるが，一 般的に，(1) 他臟器への微少転移巣の撲減，(2) 術後 再発を防止するための局所病巣の縮少化，（3）術後化 学療法の指標にするための組織学的な治療効果の判定, などを目的として施行されている

骨原発覀性腫瘍の患肢温存治療で, 腫痬摘出を確実 に行うための指標として, Enneking ${ }^{3)} に よ り$ 腫瘍の 組織学的悪性度や生体内の barrier を考慮した surgical staging system が提唱されている. そして補助 的治療を行わない場合, この systemをもとにした radical wide resction の局所再発率は $20 \%$ あるる ことを報告した。

しかし最近では，補助的治療の進歩や腫瘍浸潤領域 を適確に把握するための CT や MRI など画像診断技 術の飛躍的な発展により, 切除縁縮少の可能性が検討 されるようになった ${ }^{8)}$ 9) 13). 系統的化学療法や放射線 療法の骨原発悪性腫瘍に対する抗腫瘍効果に関する報 告は多いが 10) 11) 12), 腫瘍浸潤巣周囲にみられる反応層 に言及した研究は少ない4)9．

補助的治療によって腫瘍辺縁がどのように変化する かを明らかにすることは, 患肢温存治療で切除縁縮少 を検討する際に重要な問題であろうと考えられる. Pan et al. ${ }^{9)}$ は MR で画像で系統的化学療法の効果 の 1 つとして, 腫瘍周囲に膠原線維性被膜が出現する ことを指摘している. またGitelis et al. ${ }^{4)}$ は実験的 に移植腫瘍周囲の反応層の変化を観察し, $40 \mathrm{~Gy}$ の放
射線照射により偽被膜は腫瘍を包む様な膠原線維性被 膜に変化することを報告した。

今回の我々の研究では, 生検標本にみられた反応層 が補助的治療によって消失し, 腫瘍周囲には厚い膠原 線維性被膜が形成されることがわかった．またこの被 膜形成は腫瘍浸潤部位によってその程度に差がみられ, 骨膜周囲の疎性結合織部では著明であったが，骨骨道内 では全く認められなかった，横紋筋内では，抗腫瘍効 果がそしい場合，この被膜形成はみられなかった。

これらの事から骨外の疎性結合織内浸潤部では，腫 瘍切除の際に切除縁縮少の可能性が示唆された。しか し横紋筋内や骨髄内浸潤部では，切除縁の縮少は困難 である事を示しており，補助的治療をした場合，浸潤 部位を考慮した切除縁設定が必要であろうと思われた. 今後さらに症例数をふやし, 臨床的に温存患肢の機能 や局所再発の有無などとの対比も必要であろう.

\section{ま と め}

(1)骨原発悪性腫瘍 19 例を用い, 補助的治療前後の 腫瘍周囲組織の変化を，組織学的に観察した。

(2)補助的治療により腫瘍周囲の反応層は，腫瘍を被 包化するような膠原維組織に変わっていた。

(3)この被包化は骨膜部や骨周囲の疎性結合織部で著 明であったが，横紋筋内への浸潤部ではそしく，骨髄 内では全く認められなかった。

(4)以上, 補助的治療による反応層の変化は, 腫瘍摘 出術を確実にするために有用であるものの，その程度 は腫瘍浸潤部位により差のあることが示唆された。

\section{参 考 文 献}

1) Bacci G. at al.: Staging, therapy and prognosis of primary non-Hodgikln's lymphoma of bone and a comparison of results with localized Ewing's sarcoma: Ten years experience at the Istituto Orthopedico Rizzoli. Tumori $71:$ 345-354, 1985.

2) Bacci G. et al.: Neoadjuvant Chemotherapy for high grade osteosarcoma of the extremities: Is a good response to preoperative treatment an indication to reduce postoperative chemotherapy? Chemiotherapia 5 (2) : 140-143, 1986.

3) Enneking W.F.: Musculoskeletal tumor surgery. New York. Churchill Livingstone, 1983.

4) Gitelis S. et al.: Characterization of the pseudocapsule of soft-tissue sarcomas. An experimental study in rats. Clin. Orthop. $246: 285-292,1989$. 
5）平野 徹ほか：Ewing 肉腫に対する術前治療としての 化学療法と放射線療法併用の効果. 整形外科と災害外科, $37: 1736-1739,1989$.

6）平野 徹ほか: 補助的治療をした骨軟部悪性腫瘍切除 法の検討. 日整会誌, 63（2）：S 370，1989.

7）川口智義 : 軟部悪性腫瘍の治療. 日整会誌，58（3）: 373-390, 1984.

8) Mail J.T.: Response of osteosarcoma to preoperative intravenous high-dose methotrexate chemotherapy: CT evaluation. Am. J. Radiol. $144: 89-93,1985$.

9) Pan G. et al.: Osteosarcoma:MR imaging after preoperative chemotherapy. Radiology $174: 517-526,1990$.

10) Picci P. et al.: Histological evaluation of necrosis in osteosarcoma induced by chemotherapy. Regional mapping of viable and non-viable tumor. Cancer 56 : 1515-1521, 1985.

11) Rosen G. et al.: Neoadjuvant chemotherapy for osteogenic sarcoma:A model for the treatment of other high malignant neoplasms. Cancer Res. 103 : 148-157, 1986.

12）高田典彦 : 放射線療法を併用した骨肉腫化学療法. 臨 整外, 20 (11)：1285-1291， 1985.

13）内田淳正：上肢の患肢温存手術一Adjuvant therapy to reduction surgery の可能性について一. 日整会誌, 64 (2) : S 268, 1990

質 問国立がんセンター 中馬 広一 治療期間については, 各症例間の違いは認めないで しょうか.

臨床病理治療効果との腫瘍辺縁との関連は認めなかっ たでしょうか.

\section{解 答長崎大学 平野 徹}

術前の補助的治療期間は, 症例によって若干異なっ ていました。 その最大の理由は放射線療法が骨肉腫で $30 \mathrm{~Gy}$ から50 Gy まで巾があり，これに要した期間の 違いによるものでした。

横紋筋肉へ浸潤していた部分では, 補助的治療の効 果が著名なものほど被包化が強い傾向を示していまし た. 